\title{
Genetic Variability, Correlation and Path Analysis for Fibre Yield and Its Components in Roselle (Hibiscus sabdariffa L.) in North Coastal Zone of Andhra Pradesh, India
}

\author{
N. Hari Satyanarayana ${ }^{1^{*}}$, V. Visalakshmi ${ }^{3}$, K.V. Ramana Murthy ${ }^{3}$, K. Madhu Kumar ${ }^{3}$, \\ J. Jagannadham ${ }^{1}$, A. Upendra $\operatorname{Rao}^{3}$ and N. Venugopala Rao ${ }^{2}$ \\ ${ }^{1}$ Agricultural Research Station, Amadalavalasa, Srikakulam District, A. P. -532 185, India \\ ${ }^{2}$ Regional Agricultural Research Station (North Coastal Zone), Anakapalle, A.P. - 531 001, India \\ ${ }^{3}$ Agricultural Research Station, Ragolu, Srikakulam District, A. P. -532 484, India \\ *Corresponding author
}

\section{A B S T R A C T}

\begin{tabular}{|l|}
\hline Ke y w or d s \\
Character \\
association, Direct \\
and indirect effects, \\
$\begin{array}{l}\text { Fibre yield, Genetic } \\
\text { variability, Roselle. }\end{array}$ \\
\hline Article Info \\
\hline $\begin{array}{l}\text { Accepted: } \\
\text { 23 September } 2017 \\
\text { Available Online: } \\
\text { 10 October } 2017\end{array}$ \\
\hline
\end{tabular}

An experiment was conducted during kharif 2013 and 2014 in North Coastal Zone of Andhra Pradesh at Agricultural Research Station, Ragolu, Srikakulam district to study the genetic parameters like variability, heritability, genetic advance, correlation and path analysis for fibre yield and eleven component traits in a set of 60 genotypes of roselle (Hibiscus sabdariffa L.). Phenotypic as well as genotypic coefficients of variability were high for the important productivity characters like green weight (leafless) plant ${ }^{-1}$, dry stick weight plant ${ }^{-1}$ and fibre yield plant ${ }^{-1}$. High heritability coupled with high expected genetic advance was observed for plant height, green weight plant ${ }^{-1}$, green weight (leafless) plant ${ }^{-1}$, dry stick weight plant ${ }^{-1}$ and fibre yield plant ${ }^{-1}$. Most of the quantitative traits showed highly significant positive correlation with the dependent variable, fibre yield. Partitioning of correlation coefficients of various components upon fibre yield plant ${ }^{-1}$ into direct and indirect effects revealed that plant height has maximum direct effect followed by bark thickness and green weight plant $^{-1}$ at both phenotypic and genotypic levels. These characters therefore serve as a basis of selection for a meaningful crop improvement programme for improving fibre yield in roselle.

\section{Introduction}

Roselle (Hibiscus sabdariffa L.) belongs to the family Malvaceae; native to Asia (India to Malaysia) or Africa; and is an annual or biennial plant cultivated in Tropical and SubTropical regions for its stem, fibres, edible calyces, leaves and seeds (Mahadevan et al., 2009). Roselle is a tetraploid species with $2 n=4 x=72$ (Sabiel et al., 2014) and proved its importance in fibre industries, preparation of medicines and in culinaries to make favourable dishes from its edible parts in many countries. Roselle fibre blended with jute is used in the manufacture of jute goods viz., cordage, sacking, hessian, canvas and rough sacks, ropes, twines, fishing nets etc. The stalks were used in making paper pulp, structural boards, as a blend for wood pulp and thatching huts (Juhi Agarwal and Ela Dedhia, 2014). Roselle seed oil is richer in carotenoids than expensive oils like niger and coriander seed oil (Ramada and Morsel, 2014). Carotenoids are important ingredients 
in cosmetic industries due to their antioxidant activity and protective effect on the skin (Platon, 1997). Roselle seed flour can prevent cancer, lower blood pressure and improve the digestive systems in humans (Karma and Chavan, 2017).

Generally, success of any crop improvement program largely depends on the magnitude of genetic variability within the traits, relationship between the traits and also direct and indirect contributions of these traits for the dependant variable, yield. Yield being a complex character, is influenced by a number of yield contributing characters controlled by polygenes and influenced by environment. So, the variability in the collections for these characters is the sum total of heredity effects of concerned genes and influence of the environment. Hence, it becomes necessary to partition the observed variability into heritable and non-heritable components measured as genotypic and phenotypic coefficients of variation (GCV and PCV), heritability and genetic advance expressed as per cent mean. Correlation and path coefficient analysis will help to identify component characters in a breeding programme whose selection would result in the improvement of complex traits that are positively correlated. Keeping this in view, this study was conducted for assessing the genetic variability, heritability and genetic advance along with the relationship between traits and evaluating the direct and indirect contributions of these traits for roselle fibre yield improvement.

\section{Materials and Methods}

Sixty roselle (Hibiscus sabdariffa L.) genotypes consisting of eleven exotic lines; four released varieties and 45 indigenous accessions were evaluated in North Coastal zone, Andhra Pradesh at Agricultural Research Station, Ragolu (Latitude $18^{0} 24^{\prime} \mathrm{N}$; Longitude $83.84^{\circ} \mathrm{E}$ at an altitude of $27 \mathrm{~m}$ above mean sea level) during early kharif seasons in 2013 and 2014. The experimental trial was laid out in randomized block design with a plot size of four rows of $2 \mathrm{~m}$ length in two replications with a spacing of $30 \times 10 \mathrm{~cm}$ under rainfed conditions. Recommended package of practices was followed to raise a good crop. Data on the basis of five randomly selected competitive plants were recorded on plant height $(\mathrm{cm})$, base diameter $(\mathrm{mm})$, mid diameter $(\mathrm{mm})$, top diameter $(\mathrm{mm})$, internodal length $(\mathrm{cm})$, petiole length $(\mathrm{cm})$, nodes plant ${ }^{-}$ 1 , bark thickness $(\mathrm{mm})$, green weight plant $^{-1}$ (g), green weight (leafless) plant ${ }^{-1}(\mathrm{~g})$, dry stick weight plant $^{-1}(\mathrm{~g})$ and fibre yield plant ${ }^{-1}$ (g). Genotypic and Phenotypic coefficients of variation were calculated using the formula suggested by Burton and De Vane (1953). Heritability and genetic advance were estimated according to the formulae given by Allard (1960). Correlations were calculated as suggested by Johnson et al., (1955). The phenotypic correlations were used to find out the direct and indirect effects of the component characters according to Dewey and $\mathrm{Lu}$ (1959).

\section{Results and Discussion}

The analysis of variance revealed significant difference among the genotypes for all the twelve characters studied based on pooled mean data suggesting presence of wide variability in the germplasm studied which was also depicted by the range values of all the twelve traits (Table 1). The characters dry stick weight plant $^{-1}$, fibre yield plant $^{-1}$ and green weight (leafless) plant ${ }^{-1}$ showed high genotypic and phenotypic coefficient of variances (GCV and PCV) suggesting that these characters are under the influence of genetic control. Moderate values of genotypic and phenotypic coefficient of variances were found for the characters plant height and green weight plant $^{-1}$. Base diameter, mid diameter, internodal length, petiole length and bark thickness showed moderate PCV and 
low for GCV values revealing the influence of environment. Top diameter and nodes plant ${ }^{-1}$ showed low GCV and PCV values. Further, the estimates of PCV were generally higher than their corresponding GCV for all the characters studied suggesting thereby the importance of environment in the expression of all these traits. Hence, phenotypic selection may not hold good for genetic improvement of these traits. These findings are in agreement with Subramanyam et al., (1995), Islam et al., (2002), Mostofa et al., (2002), Bhattacharya et al., (2007), Nagaraja et al., (2009), Ghodke and Wadikar (2011), Satyanarayana et al., (2015) and Hari Satyanarayana et al., (2017).

Practically, heritability estimates are of greater value to the breeder, since, they indicate the degree of dependence of genotypic value on phenotypic value. The traits plant height, bark thickness, green weight plant $^{-1}$, green weight (leafless) plant ${ }^{-1}$, dry stick weight plant ${ }^{-1}$ and fibre yield plant ${ }^{-1}$ showed highest estimates of heritability. Moderate estimates of heritability were recorded for base diameter, mid diameter, internodal length and petiole length; low for top diameter and nodes plant ${ }^{-1}$. Similar results were also reported by Subramanyam et al., (1995), Islam et al., (2002), Mostofa et al., (2002), Bhattacharya et al., (2007), Nagaraja et al., (2009), Ghodke and Wadikar (2011), Satyanarayana et al., (2015) and Hari Satyanarayana et al., (2017).

High heritability for the traits of economic importance viz., plant height, bark thickness, green weight plant $^{-1}$, green weight (leafless) plant $^{-1}$, dry stick weight plant ${ }^{-1}$ and fibre yield plant $^{-1}$ indicated that the direct selection would be effective for improvement of these characters.

The estimates of heritability, however, indicate only the effectiveness with which the selection of genotypes can be made based on their phenotypic performance, but fail to indicate the amount of progress expected from selection. For an effective selection, the knowledge alone on the estimates of heritability is not sufficient and genetic advance (\%) of mean if studied alongwith heritability is more useful. High estimates of heritability does not always mean high genetic advance. High heritability coupled with high genetic advance of mean was observed for the traits plant height, green weight plant ${ }^{-1}$, green weight (leafless) plant ${ }^{-1}$, dry stick weight plant ${ }^{-1}$ and fibre yield plant ${ }^{-1}$. These findings were corroborated with the results of Subramanyam et al., (1995), Islam et al., (2002), Mostofa et al., (2002), Bhattacharya et al., (2007), Nagaraja et al., (2009), Ghodke and Wadikar (2011), Satyanarayana et al., (2015) and Hari Satyanarayana et al., (2017).

High heritability coupled with high genetic advance as percent of mean for these traits indicates the operation of additive genes and offer the best possibility for improvement of these traits through mass selection, progeny selection, family selection to any other suitable modified selection procedure aiming to exploit the additive gene effects (Vandana et al., 2017).

High heritability coupled with moderate genetic advance of mean was observed for the trait bark thickness indicating substantial improvement for this character could be achieved through direct selection and this trait could govern by additive type of genes. Moderate heritability coupled with moderate genetic advance of mean was observed for base diameter and internodal length indicating that these characters were less influenced by environment but governed by both additive and non-additive gene action. Hence, simple selection is suggested for further improvement in the later generation. 
Table.1 Genetic variability parameters in roselle (Hibiscus sabdariffa L.) for fibre yield and its contributing characters

\begin{tabular}{|c|c|c|c|c|c|c|}
\hline Character & Mean & Range & $\begin{array}{l}\text { GCV } \\
(\%)\end{array}$ & $\begin{array}{l}\text { PCV } \\
(\%)\end{array}$ & Heritability (\%) & GAM \\
\hline Plant height $(\mathrm{cm})$ & 308.44 & $195.82-374.38$ & 11.64 & 12.53 & 86.19 & 22.25 \\
\hline Base diameter $(\mathrm{mm})$ & 19.3 & $13.80-24.04$ & 8.36 & 10.89 & 58.88 & 13.21 \\
\hline Mid diameter (mm) & 13.83 & $9.79-16.21$ & 5.95 & 10.19 & 34.13 & 7.16 \\
\hline Top diameter (mm) & 9.52 & $7.94-11.00$ & 2.6 & 9.66 & 7.22 & 1.44 \\
\hline Internodal length $(\mathrm{cm})$ & 5.61 & $4.19-6.62$ & 7.82 & 10.52 & 55.3 & 11.98 \\
\hline Petiole length $(\mathrm{cm})$ & 10.6 & $8.17-12.76$ & 6.71 & 12.02 & 31.21 & 7.73 \\
\hline Nodes plant $^{-1}$ & 67.28 & $53.25-78.75$ & 4.52 & 8.38 & 29.09 & 5.02 \\
\hline Bark thickness (mm) & 1.97 & $1.43-2.54$ & 9.28 & 11.97 & 60.15 & 14.83 \\
\hline Green weight plant ${ }^{-1}(\mathrm{~g})$ & 524.56 & $254.90-720.85$ & 17.36 & 19.34 & 80.54 & 32.09 \\
\hline $\begin{array}{l}\text { Green weight (leafless) plant }{ }^{-1} \\
\text { (g) }\end{array}$ & 245.92 & $90.85-384.41$ & 22.78 & 25.36 & 80.69 & 42.15 \\
\hline Dry stick weight plant $^{-1}(\mathrm{~g})$ & 54.76 & $23.84-98.98$ & 27.24 & 28.32 & 92.54 & 53.98 \\
\hline Fibre yield plant ${ }^{-1}(\mathrm{~g})$ & 22.38 & $9.35-33.67$ & 25.36 & 26.62 & 90.75 & 49.77 \\
\hline
\end{tabular}


Table.2 Genotypic and Phenotypic correlation coefficients between fibre yield and its component characters in roselle (Hibiscus sabdariffa L.)

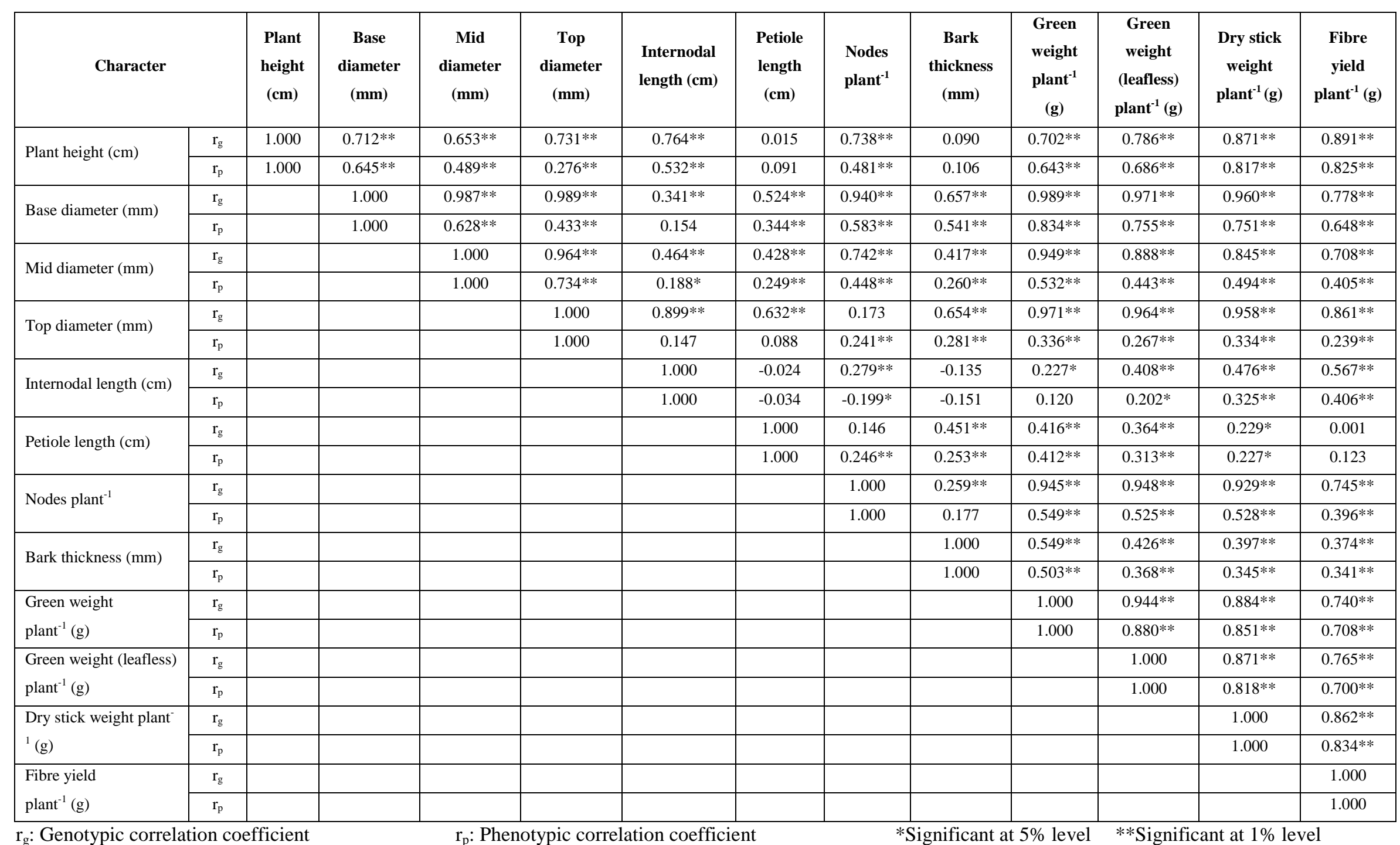


Table.3 Direct and indirect contributions of component characters for fibre yield in roselle (Hibiscus sabdariffa L.)

\begin{tabular}{|c|c|c|c|c|c|c|c|c|c|c|c|c|c|}
\hline \multicolumn{2}{|l|}{ Character } & \multirow{2}{*}{$\begin{array}{c}\begin{array}{c}\text { Plant } \\
\text { height } \\
(\mathrm{cm})\end{array} \\
0.7461 \\
\end{array}$} & \multirow{2}{*}{$\begin{array}{c}\begin{array}{c}\text { Base } \\
\text { diameter } \\
(\mathbf{m m})\end{array} \\
0.0242\end{array}$} & \multirow{2}{*}{$\begin{array}{c}\begin{array}{c}\text { Mid } \\
\text { diameter } \\
(\mathbf{m m})\end{array} \\
-0.1089 \\
\end{array}$} & \multirow{2}{*}{$\begin{array}{c}\begin{array}{c}\text { Top } \\
\text { diameter } \\
(\mathbf{m m})\end{array} \\
-0.0054\end{array}$} & \multirow{2}{*}{$\begin{array}{c}\begin{array}{c}\text { Internodal } \\
\text { length (cm) }\end{array} \\
0.1265 \\
\end{array}$} & \multirow{2}{*}{$\begin{array}{c}\begin{array}{c}\text { Petiole } \\
\text { length } \\
\text { (cm) }\end{array} \\
-0.0028 \\
\end{array}$} & \multirow{2}{*}{$\begin{array}{c}\begin{array}{c}\text { Nodes } \\
\text { plant }^{-1}\end{array} \\
0.0774 \\
\end{array}$} & \multirow{2}{*}{$\begin{array}{c}\begin{array}{c}\text { Bark } \\
\text { thickness } \\
(\mathbf{m m})\end{array} \\
0.0291 \\
\end{array}$} & \multirow{2}{*}{$\begin{array}{c}\begin{array}{c}\text { Green } \\
\text { weight } \\
\text { plant }^{-1} \\
\text { (g) }\end{array} \\
0.4365 \\
\end{array}$} & \multirow{2}{*}{$\begin{array}{c}\begin{array}{c}\text { Green } \\
\text { weight } \\
\text { (leafless) } \\
\text { plant }^{-1} \\
\text { (g) }\end{array} \\
-0.3296 \\
\end{array}$} & \multirow{2}{*}{$\begin{array}{c}\begin{array}{c}\text { Dry stick } \\
\text { weight }^{-1} \\
\text { plant }^{-1}(\mathrm{~g})\end{array} \\
-0.1021 \\
\end{array}$} & \multirow{2}{*}{$\begin{array}{c}\begin{array}{c}\text { Correlation } \\
\text { with fibre } \\
\text { yield }\end{array} \\
0.891^{* *} \\
\end{array}$} \\
\hline Plant height $(\mathrm{cm})$ & $\mathrm{G}$ & & & & & & & & & & & & \\
\hline & $\mathrm{P}$ & 0.5332 & -0.0504 & -0.0068 & -0.0169 & 0.0192 & -0.0042 & -0.0256 & 0.0215 & 0.0603 & -0.0049 & 0.2996 & $0.825 * *$ \\
\hline \multirow{2}{*}{ Base diameter $(\mathrm{mm})$} & $\mathrm{G}$ & 0.5312 & 0.0340 & -0.1646 & -0.0110 & 0.0565 & -0.0986 & 0.0986 & 0.2128 & 0.6597 & -0.4279 & -0.1124 & $0.778 * *$ \\
\hline & $\mathrm{P}$ & 0.3438 & -0.0782 & -0.0088 & -0.0264 & 0.0055 & -0.0159 & -0.0309 & 0.1099 & 0.0783 & -0.0054 & 0.2757 & $0.648 * *$ \\
\hline \multirow{2}{*}{ Mid diameter (mm) } & $\mathrm{G}$ & 0.4871 & 0.0335 & -0.1668 & -0.0086 & 0.0769 & -0.0805 & 0.0779 & 0.1350 & 0.6246 & -0.3725 & -0.0990 & $0.708 * *$ \\
\hline & $\mathrm{P}$ & 0.2610 & -0.0491 & -0.0140 & -0.0449 & 0.0068 & -0.0115 & -0.0238 & 0.0529 & 0.0499 & -0.0031 & 0.1811 & $0.405 * *$ \\
\hline \multirow{2}{*}{ Top diameter (mm) } & $\mathrm{G}$ & 0.5455 & 0.0504 & -0.1935 & -0.0074 & 0.1489 & -0.1189 & 0.0181 & 0.2119 & 0.8854 & -0.5382 & -0.1412 & $0.861 * *$ \\
\hline & $\mathrm{P}$ & 0.1470 & -0.0338 & -0.0102 & -0.0611 & 0.0053 & -0.0041 & -0.0128 & 0.0571 & 0.0315 & -0.0019 & 0.1224 & $0.239 * *$ \\
\hline \multirow{2}{*}{$\begin{array}{l}\text { Internodal length } \\
(\mathrm{cm})\end{array}$} & $\mathrm{G}$ & 0.5701 & 0.0116 & -0.0774 & -0.0067 & 0.1656 & 0.0044 & 0.0293 & -0.0438 & 0.1412 & -0.1712 & -0.0557 & $0.567 * *$ \\
\hline & $\mathrm{P}$ & 0.2834 & -0.0120 & -0.0026 & -0.0090 & 0.0360 & 0.0016 & 0.0106 & -0.0306 & 0.0112 & -0.0014 & 0.1193 & $0.406 * *$ \\
\hline \multirow[t]{2}{*}{ Petiole length $(\mathrm{cm})$} & $\mathrm{G}$ & 0.0109 & 0.0178 & -0.0713 & -0.0047 & -0.0039 & -0.1882 & 0.0154 & 0.1460 & 0.2587 & -0.1525 & -0.0269 & 0.001 \\
\hline & $\mathrm{P}$ & 0.0484 & -0.0269 & -0.0035 & -0.0054 & -0.0012 & -0.0462 & -0.0131 & 0.0513 & 0.0387 & -0.0022 & 0.0832 & 0.123 \\
\hline \multirow{2}{*}{ Nodes plant ${ }^{-1}$} & $\mathrm{G}$ & 0.5503 & 0.0319 & -0.1238 & -0.0013 & 0.0463 & -0.0276 & 0.1049 & 0.0835 & 0.5876 & -0.3975 & -0.1088 & $0.745 * *$ \\
\hline & $\mathrm{P}$ & 0.2567 & -0.0456 & -0.0063 & -0.0147 & -0.0072 & -0.0114 & -0.0531 & 0.0359 & 0.0515 & -0.0037 & 0.1938 & $0.396 * *$ \\
\hline \multirow{2}{*}{$\begin{array}{l}\text { Bark thickness } \\
(\mathrm{mm})\end{array}$} & $\mathrm{G}$ & 0.0669 & 0.0223 & -0.0696 & -0.0049 & -0.0224 & -0.0849 & 0.0270 & 0.3237 & 0.3412 & -0.1789 & -0.0465 & $0.374 * *$ \\
\hline & $\mathrm{P}$ & 0.0565 & -0.0423 & -0.0036 & -0.0172 & -0.0054 & -0.0117 & -0.0094 & 0.2031 & 0.0472 & -0.0026 & 0.1267 & $0.341 * *$ \\
\hline \multirow{2}{*}{$\begin{array}{l}\text { Green weight } \\
\text { plant }^{-1}(\mathrm{~g})\end{array}$} & $\mathrm{G}$ & 0.5236 & 0.0360 & -0.1674 & -0.0105 & 0.0376 & -0.0783 & 0.0991 & 0.1776 & 0.6220 & -0.3958 & -0.1036 & $0.740 * *$ \\
\hline & $\mathrm{P}$ & 0.3427 & -0.0652 & -0.0074 & -0.0205 & 0.0043 & -0.0191 & -0.0291 & 0.1021 & 0.0939 & -0.0062 & 0.3122 & $0.708 * *$ \\
\hline \multirow{2}{*}{$\begin{array}{l}\text { Green weight } \\
\text { (leafless) plant }^{-1}(\mathrm{~g})\end{array}$} & $\mathrm{G}$ & 0.5863 & 0.0346 & -0.1481 & -0.0095 & 0.0676 & -0.0684 & 0.0994 & 0.1380 & 0.5869 & -0.4194 & -0.1020 & $0.765 * *$ \\
\hline & $\mathrm{P}$ & 0.3660 & -0.0590 & -0.0062 & -0.0163 & 0.0073 & -0.0144 & -0.0279 & 0.0747 & 0.0826 & -0.0071 & 0.3001 & $0.700 * *$ \\
\hline \multirow{2}{*}{$\begin{array}{l}\text { Dry stick weight } \\
\text { plant }^{-1}(\mathrm{~g})\end{array}$} & $\mathrm{G}$ & 0.6502 & 0.0326 & -0.1410 & -0.0083 & 0.0788 & -0.0431 & 0.0974 & 0.1284 & 0.5498 & -0.3652 & -0.1172 & $0.862 * *$ \\
\hline & $\mathrm{P}$ & 0.4354 & -0.0588 & -0.0069 & -0.0204 & 0.0117 & -0.0105 & -0.0280 & 0.0701 & 0.0799 & -0.0058 & 0.3669 & $0.834 * *$ \\
\hline
\end{tabular}

Bold: Direct effects

Residual effect: $10.17 \%$ (Genotypic level) and 20.65\% (Phenotypic level) 
The correlation coefficients at genotypic and phenotypic levels were estimated for different pairs of characters from their pooled data of sixty roselle genotypes (Table 2). The intercharacter association with fibre yield was highly significant for all characters at both levels except for petiole length which showed non-significant relation. Fibre yield was highly significant with plant height (0.891 and $0.825)$, dry stick weight (0.862 and 0.834$)$, top diameter (0.861 and 0.239$)$, base diameter (0.778 and 0.648), green weight (leafless) (0.765 and 0.700), nodes (0.745 and 0.396), green weight $(0.740$ and 0.708$)$, mid diameter (0.708 and 0.405), intermodal length $(0.567$ and 0.406) and bark thickness (0.374 and 0.341 ) in positive direction, both at genotypic and phenotypic levels. These results are in agreement with Subramanyam et al., (1995), Islam et al., (2001), Kameswara Rao (2002), Pullibai et al., (2005), Rani et al., (2006), Bhajantri et al., (2007), Nayak et al., (2008), Pervin and Haque (2012), Satyanarayana et al., (2015) and Hari Satyanarayana et al., (2017).

High genotypic correlation coefficients than the phenotypic correlation coefficients was observed for all characters suggesting strong relationship between these characters at genetic level. The difference between genotypic and phenotypic correlations were more for the traits base diameter, mid diameter, top diameter, internodal length and nodes plant ${ }^{-1}$ suggesting high influence of environment on these traits.

Partitioning of correlation coefficients (both at genotypic and phenotypic levels) of various component characters with fibre yield plant ${ }^{-1}$ into direct and indirect contributions (Table 3) revealed that plant height (0.7461 and 0.5332$)$ had maximum direct effect on fibre yield followed by green weight plant $^{-1}(0.6220$ and $0.0939)$ and bark thickness (0.3237 and $0.2031)$ both at genotypic and phenotypic levels and dry stick weight plant $^{-1}$ at phenotypic level only. The high correlation coefficient of plant height (0.891 and 0.825) with fibre yield at genotypic level is due its own direct effect coupled with indirect effects of green weight plant ${ }^{-1}$; whereas at phenotypic level, it is due its own direct effect coupled with indirect effects of dry stick weight plant 1 . The high correlation coefficients of base diameter $(0.778$ and 0.648$)$ with fibre yield was majorly due to the indirect effects of plant height and bark thickness (at both levels) and also dry stick weight plant ${ }^{-1}$ at phenotypic level. Likewise, the high correlation coefficient of mid diameter $(0.708$ and 0.405 ) with fibre yield was also largely due to the indirect effects of green weight plant $^{-1}$, plant height and bark thickness (at genotypic level); plant height and dry stick weight plant $^{-1}$ at phenotypic level. Similarly, the high correlation coefficient of top diameter (0.861 and 0.239) with fibre yield was also largely due to the indirect effects of green weight plant $^{-1}$, plant height and bark thickness (at genotypic level); plant height and dry stick weight plant ${ }^{-1}$ at phenotypic level.

The highly significant correlation coefficient of bark thickness ( 0.374 and 0.341$)$ with fibre yield was majorly due to its own direct effects at both levels; whereas for green weight plant ${ }^{1}$ (0.740 and 0.708) was also largely due to its own direct effect coupled with indirect effect of plant height at genotypic level and indirect effects of plant height and dry stick weight plant $^{-1}$ at phenotypic level. Similarly, highly significant correlation coefficient of green weight (leafless) plant $^{-1}$ (0.765 and 0.700$)$ with fibre yield was majorly due to indirect effects of plant height and green weight plant $^{-1}$ at genotypic level and plant height and dry stick weight plant ${ }^{-1}$ at phenotypic level; whereas for dry stick weight plant ${ }^{-1}(0.862$ and 0.834 ) was also largely due to indirect effects of plant height, green weight plant ${ }^{-1}$ 
and bark thickness at genotypic level and due to its own direct effect coupled with plant height at phenotypic level.

The relationship between traits explained through character association studies may not provide a clear picture of bonding between yield and its contributing traits. Path analysis provides lucid information of direct and indirect effects of traits and measures the relative importance of each and every trait in shaping the final objective, fibre yield. The direct and indirect effects both at genotypic and phenotypic levels showed that plant height (0.7461 and 0.5332) had maximum direct effect on fibre yield followed by green weight plant ${ }^{-1}(0.6220$ and 0.0939$)$ and bark thickness (0.3237 and 0.2031); positive and highly significant correlation of these traits with fibre yield plant $^{-1}$ were also mainly due to their own direct effects. These results were corroborated with the findings of Krishnaveni and Krishnamurthy (2000), Islam et al., (2001), Anuradha and Suryakumari (2002), Kameswara Rao (2002), Nayak et al., (2008), Pervin and Haque (2012) Satyanarayana et al., (2015) and Hari Satyanarayana et al., (2017).

The influence of environment was very much high on the trait green weight plant $^{-1}$ when compared to the other two triats i.e. plant height and bark thickness which was depicted by its direct effects both at genotypic (0.6220) and phenotypic (0.0939) levels.

Based on the values of residual effects $(10.17 \%$ and $20.65 \%)$ at genotypic and phenotypic levels, respectively, it was evident that about 90\% (at genotypic level) and 80\% (at phenotypic level) of the total variations for fibre yield in roselle were explained. Finally, the path coefficient analysis revealed importance of plant height, green weight plant $^{-1}$, bark thickness and dry stick plant ${ }^{-1}$ for their contribution either directly or indirectly to fibre yield and hence, during selection these traits should be given utmost attention for developing of high fibre yielding roselle recombinants.

In conclusion, the traits plant height, green weight plant ${ }^{-1}$, green weight (leafless) plant ${ }^{-1}$, dry stick weight plant $^{-1}$ and bark thickness are very much important based on heritability, character association and path analysis studies for improving the fibre yield plant ${ }^{-1}$ in roselle.

\section{Acknowledgement}

The authors are highly thankful to the authorities of ANGRAU, Andhra Pradesh for providing necessary help and infrastructural facilities to undertake this study.

\section{References}

Allard, R. W., 1960. Principles of Plant Breeding. John Willey and Sons, Inc. London. pp. 83-108.

Anuradha, T., and Suriyakumari, S. 2002. Correlation and path coefficient analysis studies in $\mathrm{F}_{2}$ generation in mesta. Madras Agric. J., 89 (7-9): 517-518.

Bhajantri, C.M., Mummigatti, U. V. and Doddamani, M. B. 2007. Correlation studies in Mesta genotypes. Karnataka Journal of Agricultural Sciences, 20(2): 368-369.

Bhattacharya, C., Karmakar, K. S. and Bakshi, A. 2007. Study on genetic variability in capsularis jute at different population levels: A comparative study. J. Interacademicia, 11(4): 393-399.

Burton, G., and De Vane, E. H. 1953. Estimating heritability in tall fescue (Festuca arundinacea) from replicated clonal material. Agron. J., 45: 478-481.

Dewey, D.R., and Lu, K.H. 1959. A correlation and path coefficient analysis of components of crested wheat grass seed production. Agron. J., 51: 515-518. 
Ghodke, M. K., and Wadikar, P. B. 2011. Estimates of genetic variation and heritability for yield and its attributes in kenaf (Hibiscus cannabinus L.). Res. J. Agric. Sci., 2(3): 737-739.

Hari Satyanarayana, N., Manoj Kumar, V. and Visalakshmi, V. 2017. Genetic variability, character association and path analysis studis in roselle (Hibiscus sabdariffa L.) for fibre yield. Bioinfolet, 14(1): 1-4.

Islam, M. R., Islam, M. M., Akter, N. and Ghosh, R. K. 2002. Genetic variability and performance of tossa jute (Corchorus oiltorius L.). Pakistan J Biolog. Sci., 5(7): 744-745.

Islam, M.S., Uddin, M.N., Haque, M.M., Islam, M.N. 2001. Path coefficient analysis for some fibre yield related traits in white jute (Corchorus capsularis L.). Pakistan J Biological Sci. 4(1): 47-49.

Johnson, H.W., Robinson, H.F. and Comstock, R.F. 1955. Estimates of genetic and environmental variability in soybean. Agron. J., 47: 314-318.

Juhi Agarwal, and Ela Dedhia 2014. Current scenario of Hibiscus sabdariffa (Mesta) in India (Maharastra). The Inter. J. Social Sci. Humanities Invention, 1(3): 129-135.

Kameswara Rao, K., 2002. Correlation and path coefficient studies in fourty five genotypes of roselle (Hibiscus sabdariffa L.). The Andhra Agricultural Journal, 49 (3\&4): 225-227.

Karma, B.R., and Chavan, U.D. 2017. Antioxidant Activity and Nutritional Value of Roselle Seeds Flour. Int. J. Curr. Microbiol. App. Sci., 6(4): 26542663.

Krishna Veni, B., and Krishna Murthy, B. 2000. Path analysis studies in $F_{2}$ and $F_{3}$ generation of roselle (Hibiscus sabdariffa L.). Journal of Research ANGRAU, 28 (1\&2): 23-26.
Mahadevan, N., Shivali and Pradeep, K. 2009. Hibiscus sabdariffa Linn. - An overview. Natural Product Radiance, 8(1): 77-83.

Mostofa, M. G., Islam, M. R., Morshed Ala, A. T. M., Ali, S. M. M. and Mollah, M. A. F. 2002. Genetic variability, heritability and correlation studies in kenaf (Hibiscus cannabinus L.). Online J. Biol. Sci., 2: 442-424.

Nagaraja, T. E., Ajit, K. R., and Golasangi, B. S. 2009. Genetic variability, correlation and path analysis in Linseed. $J$. Maharastra Agricultural Universities, 34(3): 282-285.

Nayak, B. K., and Baisakh, B. 2008. Character association and path analysis in tossa jute. Environment and Ecology, 26(1A): 361-363

Pervin, N., Haque G.K., 2012. Path coefficient analysis for fibre yield related traits in Deshi jute (Corchorus capsularis L.). IRJALS, 1(3): 72-77.

Platon, J.F., 1997. Lipids in Cosmetology. Ol. Corps. Gras. Lipid, 4: 275-281.

Pullibai, P., Razia Sultana, Panduranga Rao, C. and Srinivasa Rao, V. 2005. Character association and path analysis in Roselle hemp (Hibiscus sabdariffa L.). The Andhra Agricultural Journal, 52 (3\&4):403-406.

Ramadan, M.F., and Morsel, J.T. 2004. Oxidative stability of black cumin (Nigella sativa L.), coriander (Coriandrum sativum L.) and niger (Guizotia abyssinica Cass.) crude seed oils upon stripping. Eur. J. Lipid Sci. Technol., 106: 35-43.

Rani, Ch., Rama Kumar, P. V., Panduranga Rao, C. and Srinivasa Rao, V. 2006. Character association, path analysis and selection indices in roselle (Hibiscus sabdariffa L.). The Andhra Agricultural Journal, 53 (3\&4): 157-159.

Sabiel, S.A.I., Ismail, M.I., Osman, A. and Sun, D. 2014. Genetic variability for 
yield and related attributes of roselle (Hibiscus sabdariffa L.) genotypes under rainfed condition in a Semi-arid zone of Sudan. Persian Gulf Crop Protection, 3(1): 33-40.

Satyanarayana, N. H., Subhra Mukherjee, Bhanu Priya and Roy, S. 2015. Genetic variability and Inter-relationship between fibre yield and its components in Roselle (Hibiscus sabdariffa L.) in Terai zone of West Bengal. Vegetos, 28(3): 135-140.
Subramanyam, D., Kumar, P. V. R., Krishnamurthy, B. and Ismail, S. 1995. Heritability and correlation studies in kenaf (Hibiscus cannabinus L.). Indian J. Genet., 55(3): 279-282.

Vandana, B., Shukla, P. S., Singh Kamendra and Vikash Kumar Singh. 2017. Morphological Characterization and Assessment of Genetic Variability in Soybean Varieties. Int. J. Curr. Microbiol. App. Sci. 6(3): 361-369.

\section{How to cite this article:}

Hari Satyanarayana, N., V. Visalakshmi, K.V. Ramana Murthy, K. Madhu Kumar, J. Jagannadham, A. Upendra Rao and Venugopala Rao, N. 2017. Genetic Variability, Correlation and Path Analysis for Fibre Yield and Its Components in Roselle (Hibiscus sabdariffa L.) in North Coastal Zone of Andhra Pradesh, India. Int.J.Curr.Microbiol.App.Sci. 6(10): 2647-2656. doi: https://doi.org/10.20546/ijcmas.2017.610.313 